\title{
IMPLIKASI PEMBINAAN PEMUDA GEREJA ATAS FAKTOR-FAKTOR PENYEBAB KASUS HAMIL DI LUAR NIKAH
}

\author{
Theresia Tiodora Sitorus \\ Universitas Kristen Satya Wacana \\ Email: theresiatiodora@yahoo.co.id
}

\begin{abstract}
This article discusses the implications of fostering church youth on the factors that cause cases of pregnancy out of wedlock. The author uses qualitative methods with data collection techniques of observation, and interviews, then in compiling the implications of the author using relevant library sources. The results showed that the factors causing cases of pregnancy out of wedlock are the lack of attention and supervision of parents, then the free association of youth, lack of self-fortification, lack of sexual knowledge, and technological developments that facilitate access to negative sexual information. The implication for church youth coaching is that holistic coaching is needed for both youth and parents. Coaching can be done by organizing groups to grow together, Christian faith seminars, personal care and making catechism curriculum on sexuality.
\end{abstract}

Keywords: courtship, sex, marriage

\begin{abstract}
ABSTRAK: Artikel ini membahas tentang implikasi pembinaan pemuda gereja atas faktor-faktor penyebab kasus hamil di luar nikah. Penulis menggunakan metode kualitatif dengan teknik pengumpulan data observasi, dan wawancara, kemudian dalam menyusun implikasi penulis menggunakan sumbersumber pustaka relevan. Hasil penelitian menunjukkan bahwa faktor-faktor penyebab terjadinya kasus hamil di luar nikah adalah kurangnya perhatian dan pengawasan orang tua, kemudian pergaulan bebas pemuda, kurangnya pembentengan diri, minimnya pengetahuan seksual, dan perkembangan teknologi yang memudahkan akses informasi negatif seksual. Implikasi bagi pembinaan pemuda gereja adalah perlu dilaksanakan pembinaan yang holistik baik pada pemuda maupun orangtua. Pembinaan dapat dilaksanakan dengan menyelenggarakan kelompok tumbuh bersama, seminar iman Kristen, personal care dan pembuatan kurikulum katekisasi tentang seksualitas.
\end{abstract}

Kata kunci: pacaran, seks, perkawinan

\section{PENDAHULUAN}

Istilah pacaran sudah hal yang lazim untuk didengar masyarakat saat ini. De Genova, Rice, Stinnett dan Stinnett (2010) memberi pengertian bahwa pacaran merupakan sebuah hubungan yang dijalankan oleh dua orang yang mana kedua orang tersebut bertemu untuk melakukan berbagai aktivitas bersama dengan tujuan agar dapat saling mengenal satu sama lain. Pacaran adalah masa persiapan menuju pernikahan dan masa paling mengenal lebih dalam antara seorang laki-laki dan perempuan. Istilah pacaran dimulai sejak pasca Perang Dunia I terjadi (setelah tahun 1918). Pada masa itu, hubungan pria dan wanita sebelum munculnya pacaran, dilakukan secara formal dengan cara pria datang mengunjungi pihak wanita dan keluarganya. Menurut Pangaribuan
(2015, p. 6) proses pacaran kemudian mulai menjadi sebuah keputusan pribadi dan adanya rasa cinta serta saling ketertarikan antara pria dan wanita menjadi dasar utama seseorang untuk menikah. Kemudian Pangaribuan menekankan bahwa saat ini telah terjadi pergeseran dalam perilaku orang berpacaran. Penyebabnya menurut Pangaribuan karena adanya orientasi berpacaran yang berpusat pada hubungan seks bukan untuk memperlihatkan keseriusan kepada tahap selanjutnya, yakni pernikahan (Pangaribuan, 2015 , p. 7). Contoh kasus diungkapkan oleh Harmadi dan Diana (2020) dalam jurnalnya yang mengatakan bahwa fenomena saat ini adalah adanya perilaku seksual yang bermasalah bahkan mengarah pada terjadinya kekerasan seksual dalam pacaran. 
Dalam Alkitab pacaran sangat dekat kaitannya dengan pertunangan dan perkawinan. Pertunangan dalam Alkitab dapat ditemukan melalui kisah pertunangan Yakub dan Rahel pada Kejadian 29:1-30. Mathews (2005, p. 456) mengatakan bahwa dalam pasal ini terlihat kesungguhan Yakub untuk membuat Rahel menjadi Istrinya. Rahel, anak perempuan Laban memiliki kerendahan hati dan ketekunan. Ia tetap menggembalakan kambing domba ayahnya (ay. 9), walaupun ia memiliki hamba-hamba yang diperkerjakan ayahnya untuk menjagai kambing domba itu. Ketika Yakub bertemu dengan Rahel, ia terpesona oleh wajah Rahel yang alami dan elok, lalu langsung terbersit dalam pikirannya bahwa Rahel harus menjadi istrinya. Kemudian, Yakub memberitahu Laban tentang perasaannya kepada Rahel. Karena tidak mempunyai harta duniawi di tangannya untuk mempersunting Rahel, Yakub kemudian berjanji bahwa ia akan bekerja selama tujuh tahun kepada Laban, dengan persyaratan bahwa, setelah masa tujuh tahun itu berakhir, Laban bersedia mengizinkan Rahel menikah dengannya. Yakub kemudian bekerja selama tujuh tahun untuk mendapatkan Rahel dan dengan jujur Yakub melayani selama tujuh tahun sebagaimana telah dijanjikannya. Bahkan, ia menjalankannya dengan senang hati: Tetapi yang tujuh tahun itu dianggapnya seperti beberapa hari saja, karena cintanya kepada Rahel, seolah-olah ia lebih ingin mendapatkan Rahel dengan bekerja daripada memilikinya begitu saja. Perhatikanlah, kasih yang tulus membuat pekerjaan-pekerjaan yang lama dan sulit menjadi sebentar dan mudah. (Mathews, 2005, p. 457).

Masa kerja tujuh tahun itu diperhitungkan sebagai mas kawin. Kebiasaan membayar mas kawin ini merupakan bukti pengakuan bahwa wanita memang berguna dan sebagai ganti rugi kepada keluarga atas hilangnya tenaga kerja karena perkawinan. Bagi Yakub yang sangat mencintai Rahel, tujuh tahun terasa cepat berlalu. Tetapi pada saat Yakub menerima bayaran dari apa yang ia kerjakan dari Laban, Laban memberikan putrinya yang lebih tua, yaitu: Lea. Yakub tidak mengetahui bahwa Laban me- nipunya. Karena pada zaman itu calon pengantin wanita memakai cadar yang tebal, selama berlangsung upacara di tengah kegelapan ia dikawal banyak orang. Kemudian pada zaman itu juga, pesta perkawinan berlangsung selama 7 hari (Hak. 14:10-18) dan dalam masa 7 hari itu pun pengantinnya sudah boleh melakukan hubungan seks sehingga Yakub tidur dengan istrinya (Viviano, 2002, p. 66). Dari kisah Yakub dan Rahel ini terlihat bahwa hubungan seks boleh diijinkan sesudah pesta perkawinan. Oden (2006, p. 37) mengatakan bahwa perkawinan adalah ikatan suami-istri yang direncanakan oleh Allah dan dipenuhi kasih, saling pengertian, damai sejahtera, serta kebahagiaan. Karena itu, kekudusan dalam perkawinan sangat dibutuhkan dan itu selalu berhubungan dengan seks yang merupakan milik suami dan istri. Dalam 1 Korintus 7:5, Paulus mengingatkan orang Korintus untuk menghormati komitmen perkawinan yang sudah dilakukan. Hubungan perkawinan adalah suatu kewajiban seseorang yang memiliki otoritas atas tubuh orang lain secara timbal balik. Paulus meneruskan pembelaannya mengenai perkawinan dengan mengajukan alasan bahwa kesetiaan perkawinan lebih baik dari percabulan seks. Mereka yang memilih perkawinan harus setia dan saling menghormati. Para suami dan istri memiliki satu sama lain. Persatuan antara suami dan istri yang demikian mencerminkan tata penciptaan. Perkawinan dalam Kekristenan tidak boleh ada eksploitasi, dominasi, atau penekanan, melainkan pemberian yang bebas dan berbalasan atas dirinya kepada pasangannya. Bila harus ada yang menghindari hubungan seksual, hal itu haruslah dilakukan dengan persetujuan bersama. Menjauhi pasangan berarti menyangkal hak-hak perkawinan pasangan, dan itu sama dengan mencuri. Paulus mengatakan lakukanlah pertahanan diri; tetapi jadikanlah itu sebagai pengecualian dan bukan sebagai sesuatu yang umum. Pastikanlah bahwa kamu berdua setuju dengan tindakan tersebut, dan jangan melakukannya secara berlebihan bila tidak, Iblis akan menggunakan niat-niat yang saleh untuk membawa seseorang ke dalam jebakan. 
Mencermati perkembangan pola berpacaran, pada abad 20-an sebelum seseorang membangun rumah tangga, kebanyakan dari laki-laki dan perempuan masuk dalam proses pengenalan lebih dalam, yakni: berpacaran terlebih dahulu. Tetapi para pemuda millennial ada yang menganggap bahwa pacaran itu merupakan sebuah tradisi yang tidak tertulis. Pikiran-pikiran seperti inilah yang sudah melekat dipikiran para pemuda sekarang yang membuat makna pacaran itu menjadi bergeser dan berkurang maknanya. Berdasarkan apa yang bisa disaksikan saat ini, ada pemuda yang melakukan pacaran mengarah ke arah yang negatif, sikap dalam berpacaran terlalu bebas tanpa berlandaskan nilai moral dan agama yang seharusnya menjadi prioritas utama. Itu terbukti dari adanya pemuda yang menjadi korban akibat bentuk pacaran yang negatif. Hubungan pacaran yang negatif, sehingga mengakhiri pendidikannya dikarenakan sudah hamil di luar nikah dan harus menikah. Keadaan yang seperti inilah dapat mengancam, baik di masa kini, maupun di masa-masa yang akan datang. Bukan hanya hamil di luar nikah, tetapi seks bebas dan aborsi juga akan dampak dari pacaran yang tidak berlandaskan nilai moral dan agama. Hal ini dapat dibuktikkan, di Indonesia sendiri kasus seks bebas setiap tahun semakin meningkat jumlahnya, umumnya di kota-kota besar.

Survei Badan Kependudukan dan Keluarga Berencana Nasional (BKKBN) pada tahun 2010, seperti dituliskan oleh Andriani (2014) menunjukkan 52 persen pemuda di Medan sudah melakukan seks bebas dan mengakibatkan penyakit Infeksi Menular Seksual (IMS). Angka ini menunjukkan bahwa jumlah pemuda yang melakukan seks bebas sudah semakin banyak. Perilaku seks bebas yang melanda para pemuda sering sekali menimbulkan kecemasan para orang tua, pendidik, pemerintah, para ulama, dan lain-lain. Selain jumlah kasus seks bebas, jumlah kasus aborsi juga mengalami peningkatan. Departermen Kesehatan RI mencatat bahwa setiap tahunnya terjadi 700 ribu kasus aborsi pada pemuda. Prosentasenya adalah 30\% dari total 2 juta kasus, dilakukan oleh dukun. Penelitian PKBI menunjuk- kan tahun 2005 di 9 kota mengenai aborsi dengan 37,685 responden, $27 \%$ dilakukan oleh klien yang belum menikah dan terdapat kasus dimana klien sudah mengupayakan aborsi terlebih dahulu secara sen-diri dengan meminum jamu khusus. Sementara 21,8\% dilakukan oleh klien dengan kehamilan lanjut dan tidak dapat dilayani permintaannya (Andriani, 2014).

Semakin meningkatnya jumlah kasus hamil di luar nikah, seks bebas, dan aborsi setiap tahunnya disebabkan karena kurang hati-hatinya pemuda tersebut dalam menjalani masa pacaran. Masa pacaran tidak difungsikan sebagai masa untuk menjajaki sikap, perilaku, pola pikir dan kepribadian pasangannya, melainkan digunakan untuk hal-hal yang berkaitan dengan seks dan membangkitkan birahi.

Dalam pengamatan penulis, kasus hamil di luar nikah sebagai akibat dari pacaran yang tidak benar terjadi di banyak gereja. Hanya dalam penelitian ini, penulis mencermati kasus yang terjadi di lingkungan Huria Kristen Batak Protestan (HKBP) di Kota Pematangsiantar, Provinsi Sumatera Utara. Dalam penelitian awal terhadap data yang dimiliki oleh HKBP, ada beberapa pemuda yang mengalami masalah pacaran hingga terjadi hamil di luar nikah. Persoalan ini perlu ditangani untuk meminimalkan permasalahan. Oleh sebab itu perlu diteliti faktor penyebabnya kemudian dikemukakan implikasi bagi pembinaan pemuda di lingkungan HKBP.

Rumusan masalah dalam penelitian ini adalah apa faktor-faktor penyebab kasus hamil di luar nikah dan implikasinya bagi pembinaan pemuda gereja? Tujuan penelitian ini adalah memaparkan faktor-faktor penyebab kasus hamil di luar nikah dan implikasinya bagi pembinaan pemuda gereja.

\section{METODE}

Metode penelitian yang penulis gunakan adalah metode kualitatif karena peneliti berusaha menemukan dan menggambarkan secara naratif kegiatan yang dilakukan dan dampak dari tindakan yang dilakukan (Anggito \& Setiawan, 2018, p. 7). Dalam penelitian kualitatif ini penulis berusaha 
mengungkap data lapangan untuk memberikan informasi yang jelas terhadap apa yang disajikan dalam laporan penelitian (Anggito \& Setiawan, 2018, p. 11). Pendekatan kualitatif dapat dipilih dalam penelitian keagamaan karena dapat membantu menganalisis permasalahan dan mencari makna secara mendalam serta membantu pengembangan gereja (Purwanto, 2016; Zaluchu, 2020). Dalam melakukan penelitian ini, penulis secara langsung meneliti kondisi yang terjadi dalam lapangan. Tehnik pengumpulan data yang digunakan penulis untuk menambah informasi dan menganalisis data adalah studi kepustakaan, observasi, dan wawancara. Data lapangan yang disajikan penulis berisikan uraian-uraian informasi yang didapat penulis dari informan. Setiap data dituangkan penulis melalui kata-kata dan tidak berupa angka-angka atau rumus-rumus. Penulis memulai dengan menjelaskan makna pacaran dalam Alkitab dan makna perkawinan yang didapat penulis dari studi kepustakaan, kemudian penulis mendes- kripsikan hasil informasi yang didapat penulis dari lapangan tentang faktor-faktor penyebab dari kasus hamil di luar nikah. Untuk menemukan faktor-faktor penyebab kasus hamil di luar nikah ini, penulis mengambil 5 informan yang berasal dari pasangan suami-istri yang hamil di luar nikah dari beberapa gereja HKBP di Kota Pematangsiantar, Provinsi Sumatera Utara. Penulis merahasiakan identitas pribadi informan atas pertimbangan etis, tetapi data yang penulis sajikan sesuai dengan hasil fieldnote.

\section{HASIL DAN PEMBAHASAN}

\section{Faktor-Faktor Penyebab Kasus Hamil di Luar Nikah}

Berdasarkan penelitian lapangan yang dilakukan oleh penulis, penulis menemukan faktor-faktor penyebab pacaran yang negatif. Dalam hal ini penulis menyebutnya sebagai pacaran yang tidak Kristiani.

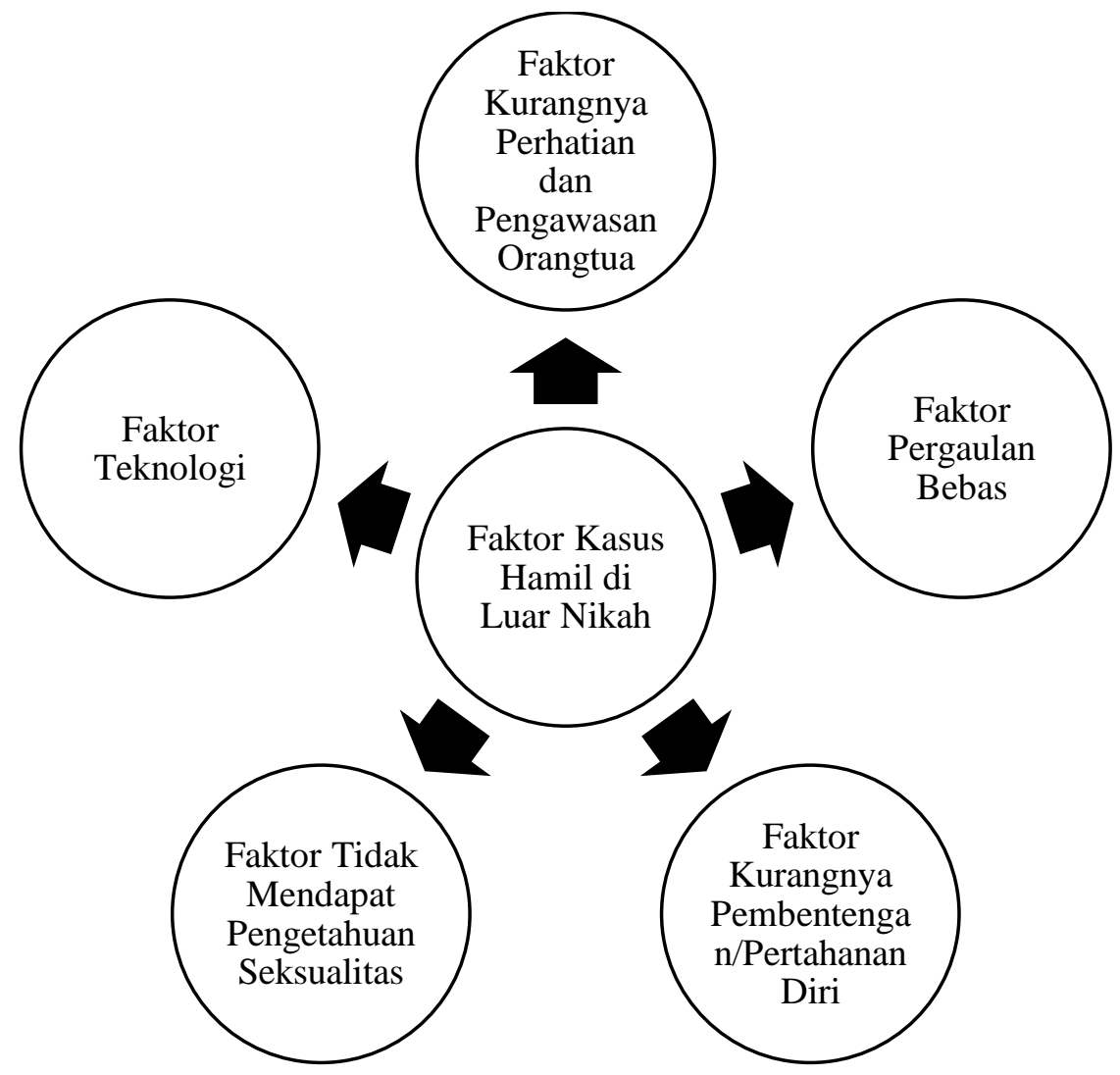

Gambar 1.Faktor Kasus Hamil di Luar Nikah 


\section{Perhatian dan Pengawasan Orangtua}

Kurangnya perhatian dan pengawasan dari orang tua menjadi salah satu faktor utama yang membuat terjadinya pacaran yang negatif sehingga menghasilkan kasus hamil di luar nikah. Orang tua sibuk dengan pekerjaannya sehingga perhatian dan arahan terhadap anak-anaknya sangat kurang diberikan. Kurangnya perhatian dan pengawasan dari orang tua mengakibatkan seorang anak mudah terbujuk oleh perilaku mesra lawan jenis yang lebih dewasa. Belaian, perhatian, ciuman dan pelukan dipandang merupakan wujud dari kasih sayang. Dalam kondisi mental labil, seorang anak muda akan mudah sekali dibujuk melakukan hubungan seksual oleh predator yang lebih dewasa maupun seusia (Magdalena, 2010, p. 33). Hal inilah yang dialami oleh ES dan MS. ES (2019) menjelaskan bahwa mulai dari kecil ia kurang mendapat perhatian dari kedua orang tuanya. Tetapi ketika ia berpacaran, perhatian itu ia dapat dari sang pacar. Sang pacar sering memberikan barang-barang yang ia minta. Kemudian sang pacar memanfaatkan keadaan ES dengan terus merayunya untuk melakukan hubungan intim dan pada saat itu posisi ES juga sedang menyusun skripsi yang tidak selesai, ditambah juga ES bermasalah dengan dosen pembimbing skripsinya, akhirnya ia menyetujui permintaan pacarnya. Sedangkan pada kasus MS (2019) menunjukkan bahwa orang tuanya juga tidak pernah menanyakan bagaimana kuliahnya dan pergaulannya terkhusus hubungan pacarannya. Orang tua MS selalu sibuk dengan pekerjaannya dan hanya memberikannya uang untuk keperluannya. MS mengatakan memang dalam keluarganya, keharmonisan keluarga itu kurang diperhatikan. Padahal orang tua MS adalah orang tua yang berasal dari latar belakang pendidikan dan pekerjaan yang baik. Dalam keluarga tidak pernah ada waktu untuk kumpul bersama-sama bahkan untuk doa bersama dan makan bersama tidak pernah dilakukan. MS mengikuti rayuan yang diungkapkan oleh sang pacar untuk melakukan hubungan intim. Hal ini dilatar-belakangi oleh orang tua yang tidak memberikan perhatian dan terlalu sibuk dengan pekerjaan- nya. Ketika orang tua gagal dalam menanamkan nilai-nilai dalam diri anak dan kurang memfasilitasi perkembangan karakter yang baik, maka anak akan mencari nilai-nilai dari luar dan pembentukan karakter akan bergantung pada peneladanan di lingkungan sosial yang lebih luas (Magdalena, 2010, p. 32).

Lingkungan keluarga menjadi salah satu lingkungan yang utama dimana anak bertumbuh dan dibimbing dengan karakter kepribadian yang baik. Mariani dan Diana (2020) lingkungan keluarga memberi dua pengaruh bagi pertumbuhan anak, dapat menjadi penunjang pertumbuhan anak yang baik, atau malah menjadi penyesat bagi anak. Oleh karena itu, orang tua sangat berperan untuk memberikan pembekalan bagi anak dalam dalam mengantarkan anak memasuki remaja dan bergabung dengan kelompok usia sebayanya. Menjadi nak yang berguna untuk kehidupan pribadinya, orang lain, dan lingkungan lebih luas tergantung didikan dari keluarga si anak. Di dalam keluarga, orang yang memiliki kuasa dan yang sangat berperan adalah orang tua. Orang tualah yang menjadi bertanggung-jawab untuk memberikan didikan dan arahan yang baik terhadap anak melalui perhatian setiap hari. Selain bekerja untuk mencari nafkah, orang tua harus memberikan waktu untuk berkomunikasi kepada anak bagaimana kehidupan dan pergaulannya di luar lingkungan keluarga. Jika orang tua mendidik anak secara benar dan memberikan perhatian melalui waktu yang disiapkannya untuk berkomunikasi kepada anak, maka anak akan tumbuh menjadi anak yang memiliki pribadi yang baik dan tidak terpengaruh oleh lingkungan di luar keluarga.

\section{Pergaulan Bebas}

Pergaulan merupakan suatu hubungan antar manusia sebagai mahkluk sosial yang tidak dapat dihindarkan. Pergaulan tersebut dapat berupa hubungan reaktif saja, dimana antara dua individu atau lebih hanya terjalin hubungan bagaikan tanya-jawab saja. Menurut Illua (2020) pergaulan yang dimiliki si anak dapat memberikan pengaruh bagi tumbuh kembangnya dan dapat membentuk karakter si anak, 
baik karakter yang baik ataupun karakter yang tidak baik. Terdapat pergaulan antar individu yang bersangkutan aktif dan kreatif menciptakan hubungan dimana masing-masing saling memajukan tarif kehidupannya dan saling menyempurnakan martabatnya. Akan tetapi pergaulan dapat menimbulkan masalah, hingga akhirnya dapat menimbulkan kesulitan bagi orang yang bersangkutan (Gunarsa \& Gunarsa, 1987, p. 36). Pergaulan yang menimbulkan persoalan dan cenderung terlalu bebas tanpa pengawasan orangtua disebut pergaulan bebas. Anwar, Martunis, dan Fajriani (2019) mengungkapkan ketika anak sudah masuk dalam pergaulan bebas, si anak akan mengalami kesadaran dan pengontrolan diri yang kurang terhadap hal-hal yang tidak sesuai dengan norma-norma agama, adat istiadat maupun kaidahkaidah berlaku dalam masyarakat. Selain itu, si anak sering keluar larut malam, bergaul dengan lawan jenis tanpa adanya batasan, bullying, mengakses konten pornografi, berpenampilan tidak sesuai dengan umur, melanggar aturan sekolah dan sejenisnya.

Pergaulan bebas berdampak pada hubungan seks bebas di kalangan remaja dan pemuda. Pengaruh pergaulan bebas menentukan, dimana kadang awalnya hanya mencoba-coba, lama-kelaman menjadi ketagihan dan terbiasa. Ketika pergaulan itu menyediakan gambar atau tulisan berbau seks, akan meningkatkan secara langsung nafsu dari seseorang. Nah, jika tidak dibekali dengan pengetahuan mengenai seks dan dibentengi dengan moral, maka nafsu birahi yang ia miliki dapat membawanya untuk melakukan aktivitas seks (Magdalena, 2010, p. 33). Hal inilah yang dialami oleh MS dan SELS. MS (2019) mengatakan bahwa ia hamil di luar nikah karena dia memiliki pergaulan yang bebas tanpa pengawasan orang tuanya. Ia sering menginap di kost-kostan temannya, ia juga sering ke cafe, ia juga sering menonton video porno, bahkan ia pernah mencoba shabu-shabu. Pergaulan yang bebas tanpa pengawasan orang tua juga membawanya kepada hubungan pacaran yang negatif. Selama MS (2019)berpacaran, sudah beberapa kali melakukan hubungan intim bersama pacarnya sampai pada akhirnya ia hamil. Hal yang serupa juga dialami oleh SELS (2019), karena pergaulan bersama teman-temannya dan lingkungan yang membuat ia terlalu bebas dalam berpacaran sampai pada akhirnya SELS hamil.

Selain itu, pergaulan dan lingkungan yang menganggap berciuman antara lelaki dan perempuan adalah hal biasa, termasuk berpegangan tangan, pelukan, atau bahkan yang lebih jauh lagi adalah hal yang lumrah, maka akan menganggap semua aktivitas yang mengarah pada perilaku seks itu biasa saja, dan merasa wajar melakukannya juga. Hal inilah yang dialami oleh SELS (2019).

\section{Pembentengan/Pertahanan Diri}

Kurangnya pembentengan/pertahanan diri dari si pemuda juga menjadi salah satu faktor. Rayuan yang diungkapkan oleh si laki-laki pada umumnya tidak mampu ditolak oleh perempuan. Mereka ditipu oleh kebaikan dan perkataan manis yang dilakukan oleh pasangannya. Pemberian uang dan barang-barang terhadap perempuan menjadi salah satu kebaikan yang diberikan laki-laki pada pasangannya sehingga dengan itu si perempuan tidak sanggup menolak rayuan si laki-laki (ES, 2019). Masalah yang terjadi pada perempuan adalah perempuan tidak mampu membentengi dirinya dengan hal-hal duniawi dan ketika diwawancarai SELS (2019) mengaku bahwa spritualitasnya juga sangat kurang/jarang pergi ke gereja. Gaol dan Stevanus (2019) krisis spiritualitas sebagai akar dari krisis moralitas. Krisis spiritualitas dapat menjadi salah satu awal dari krisis moralitas yang kemudian dapat mengarah pada perilaku seks bebas di kalangan remaja. Zohar dan Marshall (2001) mengatakan spiritualitas yang baik membuat manusia menjadi kreatif untuk hidup dalam batasan, mampu membedakan, memberi rasa moral, dan mampu menyesuaikan diri dengan aturan dibarengi dengan pemahaman dan cinta pada batasan. Karena itu, dengan spiritualitas yang baik, seseorang akan sadar bahwa seks itu adalah bagian dari anugerah Tuhan. Seks adalah anugerah dari Allah yang diberikan kepada laki - laki dan perempuan yang bersifat agung. Karena anugerah Allah yang 
agung maka seks pertama kali dilakukan sesuai dengan waktu yang ditentukan. Menurut Mile(2000, p. 106), seks anugerah yang agung itu hanya dapat dilakukan pada pernikahan. Ia mengatakan bahwa melakukan seks dengan bebas sebelum pernikahan adalah dosa. Karena hanya di dalam sebuah pernikahanlah peneguhan janji dari ikatan yang suci antara lakilaki dan perempuan yang menghadirkan seksualitas didalamnya. Seks adalah milik dari sebuah pernikahan dan inilah yang menunjukkan kemurnian dari sebuah pernikahan Kristen (Miles, 2000, p. 106). Ketika Allah menciptakan perempuan dan laki-laki dalam rupanya, ia memberikan kebebasan pada laki-laki dan perempuan itu. Allah memberikan kebebasan kepada manusia dan manusia harus bertanggung-jawab untuk itu. Kebebasan yang bertanggung-jawab itu harus berdasarkan hukum yang ada, yaitu: memperhatikan alam, moral, dan Ilahi. Inilah kebebasan yang terberkati. Sama halnya dengan seseorang yang melakukan seks. Seseorang yang tidak menggunakan kebebasan yang bertanggungjawab dalam hubungan seksnya, maka seks itu bukan menjadi berkat melainkan kutuk. Terbukti dari semakin seseorang itu melakukan hubungan seks secara bebas, maka ia semakin muda mengalami penyakit kelamin dan menghancurkan kesehatannya, keluarganya, dan kehidupan sosialnya. Hubungan seksual dan gairah seksual yang tidak terbatas adalah milik pernikahan.

Seks adalah karunia Tuhan untuk kebahagiaan manusia. Karena itu seks perlu untuk dipelihara dengan baik dan dijunjung, selain itu juga perlu dihormati dan dihargai. Sebab ketika meremehkan seks, maka akibatnya ialah kerusakan jasmani dan rohani pada diri sendiri. Suatu sikap hidup yang jelas yang berlandaskan pada perintah Tuhan akan membantu seseorang menegakkan kehidupan yang suci dan mulia (Tu'u, 2000, p. 13).

\section{Pengetahuan Seksualitas}

Ketika seorang anak tidak mendapat pengetahuan tentang seksualitas sejak kecil dari lingkungan keluarga, yakni: orangtua tidak mengajari tentang kegunaan dari anggota-anggota tubuh dan bagaimana ia harus menjaga tubuh terkhusus si perempuan, maka ia akan menganggap anggota-anggota tubuh yang ada pada dirinya tidak memiliki kekhususan waktu untuk digunakan/tidak perlu dijaga (terkhusus alat kelaminnya). Sehingga ia dapat melakukan hubungan intim bersama pacarnya dengan bebas tanpa memikirkan dampaknya. Hal inilah yang dialami oleh MS (2019) dan ES (2019) yang memang tidak pernah mendapat pengetahuan tentang seksualitas dari orang tuanya. Harmadi dan Diana (2020) pendidikan seksualitas sangat perlu untuk bekal bagi si anak memasuki usia remaja karena pada usia remaja minat heteroseksual mereka secara perlahan mengarah kepada orang tertentu dari jenis seks yang berlawanan, mulai dari perhatian yang lebih bersifat genital menuju perhatian yang bersifat erotis. Gaol dan Stevanus (2019) berpendapat jika anak-anak tidak diajar pendidikan seks sedini mungkin, maka terjadi kemungkinan besar akan mengarah pada pergaulan bebas, seks bebas, pemerkosaan, sodomi, hamil diluar nikah, aborsi, hidup bersama diluar nikah, dan pelanggaran-pelanggaran nilai-nilai moral lainnya. Dengan demikian, remaja memerlukan pendidikan seks, bahkan dapat dimulai sejak masih kanak-kanak. Perkembangan teknologi memudahkan akses informasi sehingga anak-anak dan remaja menjadi rentan terhadap informasi yang salah mengenai seks. Pendidikan seks pada anak dan remaja dapat memberitahu berbagai perilaku seksual berisiko yang harus dihindari. Pendidikan seks harus dianggap sebagai bagian dari proses pendidikan untuk memperkuat pengembangan kepribadian.

Menurut Chalke (2007, p. 32), ketika si anak berada dalam tahap masa puber, maka hormon yang dimiliki akan meningkat dan bergejolak di dalam tubuh serta memerintahkan bagian-bagian tertentu berubah menuju dewasa. Hormon estrogen berfungsi untuk mengendalikan siklus reproduksi anak perempuan, memerintahkan indung telur melepaskan telur ke leher rahim setiap bulannya. Hormon testosteron berfungsi mengawasi produksi sprema pada anak laki-laki (Chalke, 2007, p. 32). Pada anak perem- 
puan, buah dada mulai berkembang dan mulai tumbuh rambut di ketiak atau pangkal paha mereka. Lalu, mereka mulai menstruasi. Menstruasi menandakan anak perempuan sudah mulai dewasa. Perkembangan anak laki-laki rata-rata lebih lambat satu tahun atau lebih dibandingkan anak perempuan. Tubuh anak laki-laki mulai bertambah tinggi dan berotot, serta tumbuh rambut di wajah dan pangkal paha. Suara mereka membesar, juga testis mereka, mereka pun memasuki dunia ereksi dan ejakulasi. (Chalke, 2007, p. 33).

Perubahan-perubahan fisik tersebut adalah bagian kecil dibanding dengan pengaruh emosional yang dibangkitkan oleh masa puber itu. Kegelisahan, depresi, atau kurangnya rasa kepercayaan diri akan menjadi tantangan emosional yang dihadapi anak pada msa pubertas. Bertemu dengan lawan jenis akan meningkatkan kegelisahan dan hasrat yang sebelumnya tidak pernah memikirkan berubah menjadi sesuatu yang menyenangkan dan ingin memiliki. Selain itu, dari tidak pernah benar-benar berpikir mengenai seks, mereka tiba-tiba mendapat dirinya selalu memikirkan tentang seks dari keadaan tanpa hasrat, yang kemudian tanpa disangka mereka kini menjadi selalu penuh hasrat (Chalke, 2007, p. 34).

Seorang perempuan sudah boleh merencanakan sebuah pernikahan adalah umur 24 tahun karena dianggap sudah matang secara biologis dan jiwa. Pacaran mestinya sudah boleh berlangsung. Sebuah statistik psikologi menyebutkan bahwa pacaran tidak boleh terlalu lama. Lama pacaran ideal itu sekitar dua tahunan. Lebih lama dari itu berisiko putus dan lebih pendek dari dua tahun kemungkinan belum tentu saling menemukan kecocokan untuk hidup bersama (Nadesul, 2009, p. 44).

Hubungan dengan lawan jenis menyentuh suatu dorongan fisik yang sangat kuat dari manusia sehingga menimbulkan banyak pencobaan. Kecenderungan terulangnya kontak fisik akan semakin terjadi jikalau pacaran yang dibangun eksklusif dan tidak sehat. Lelaki dan wanita yang terlibat dalam kontak fisik selama berhubungan dan bahkan penyelewengan seks itu sulit mengatakan "tidak" apabila ada kesempatan yang terbuka untuk itu. Kebutuhan biologisnya terasa semakin bertambah dan kuat sekali seolah-olah hal itu telah membius diri mereka sehingga memerlukan pemuasan segera. Jika dorongan biologis ini tidak terpenuhi dengan cepat, maka sering terjadi salah paham, pertengkaran, amarah, rasa mudah tersinggung yang keterlaluan sehingga tidak jarang menimbulkan kekalapan. Apabila terjadi kehamilan yang tidak dapat dipertanggungjawabkan, maka pada umumnya rasa malulah yang mengguncang batin pihak wanita (Tu'u, 2000, p. 20). Jika seseorang pun tidak pernah menolak, maka ketika seseorang memiliki jarak jauh dengan pasangan anda akan menciptakan kerinduan yang diperlukan oleh seksualitas (Towsend \& Cloud, 2008, p. 76).

Menurut Chalke, orangtua sangat berperan dalam mendidik anaknya supaya dapat berpacaran dengan positif terkhusus memberikan anak-anaknya pendidikan seksual. Pendidikan seksual merupakan salah satu bagian terpenting dari pendidikan biasa (Chalke, 2007, p. 19). Banyak orangtua mengatakan bahwa tugas mereka ialah mendidik anak-anak mereka agar dapat hidup dengan sopan dan suci. Sesuai dengan itu mereka, tidak mau membicarakan soalsoal seks dan seksualitas dengan anak-anak mereka. Tetapi mereka lupa, bahwa sama seperti anak-anak yang lain, demikian pula anak-anak mereka suatu saat ingin mengetahui dari mana datangnya seorang bayi, bagaimana bayi itu dibuat, dan lain-lain. Karena anak-anak mereka tidak mendapat penjelasan dari mereka, anak-anak itu mengusahakan penjelasan itu dari kawan-kawan mereka - di sekolah atau di luar sekolah - atau dari "stensilan-stensilan gelap" yang dapat mereka peroleh. Hal itu sangat berbahaya, bukan saja karena penjelasan yang mereka peroleh dari kawan-kawan mereka itu tidak selalu benar dan tidak selalu diberikan "dalam bentuk yang sopan", melainkan juga karena impresi atau pengetahuan yang salah tentang seks dan seksulitas dapat mempunyai pengaruh yang buruk atas kehidupan seksual mereka. Selain itu, sikap yang negatif dari orang tua terhadap soal-soal seks dan seksualitas da- 
pat memberikan kesan kepada anak-anak, seolaholah persoalan itu adalah buruk dan kotor, karena itu tidak boleh dibicarakan. Selain itu, sebagian orang tua menerapkan prinsip bahwa anaknya tidak membutuhkan pendidikan seksual karena adanya ketakutan jika terlalu banyak memperoleh informasi tentang pengetahuan seksual maka akan mendorong anak mereka pada melakukan hubungan seks terlalu dini (Chalke, 2007, pp. 29-30). Oleh sebab itu, orangtua memilih untuk menunda memberi informasi tentang seks pada anak mereka sampai dirasa bahwa itu adalah kebutuhan yang benar-benar mendesak. Pada dasarnya tujuan mereka baik, tetapi ketika mereka tetap mungkin justru lebih menjerumuskan daripada membantu anak-anak mereka. Pada sisi lain anak dapat menjadi sangat tidak komunikatif dengan orang tua mereka, terutama yang berkaitan dengan hal pribadi dan membuat mereka malu seperti masalah pacaran. Bahkan ada kemungkinan orang tua adalah orang terakhir yang akan mengetahuinya. Jadi jika orang tua ingin menunggu sampai detik-detik terakhir sebelum merampas kepolosan mereka yang berharga, kemungkinan besar ada orang lain telah lebih dulu. Ketika orangtua menerapkan prinsip diam adalah emas, maka mereka akan melewatkan beberapa kesempatan terpenting dalam membantu mereka menyiapkan masa depan, serta apa yang disebut dengan dimulainya proses metamorfosis perlahan dari anak laki-laki atau perempuan menjadi pria atau wanita dewasa. Oleh sebab itu sangat diperlukan sebuah bimbingan yang terbuka dan jujur dari orang tua terhadap seksualitas untuk membantu mereka membuat pilihan-pilihan yang lebih baik, memiliki dasar, dewasa dan bertanggung jawab dalam menghadapi tekanan berat dari hormon, teman-teman, dan media. Tanggung jawab orangtua adalah membantu anak mereka memahami serta mampu mengendalikan keinginan hati dan emosi mereka, memanfaatkan kekuatan dorongan seksual mereka agar dapat bekerja untuk mereka (Chalke, 2007, p. 31). Sujarwati, Yugistyowati, Haryani(2014) menjelaskan bahwa setiap orang tua berhak memberikan pemahaman tentang seksual kepada anaknya dan mengajar- kan fungsi dari alat reproduksi yang ada pada tubuh manusia. Dari hal ini anak remaja dapat memahami perilaku seksual yang tepat dan dapat mengembangkan perilaku seksual yang sehat.

\section{Faktor Teknologi}

Illua dan Masihoru (2020) menjelakan bahwa terkontaminasi dengan teknologi yang memiliki daya kecepatan tinggi untuk menyebarkan berita positif dan berita negatif yang sangat berpengaruh terhadap perilaku seks pranikah. Teknologi yang semakin berkembang pesat menjadi faktor terakhir dari penyebab pacaran yang negatif di kalangan pemuda yang mengakibatkan hamil di luar nikah. Mulai dari adanya telepon genggam, televisi, radio, bahkan internet, membuatnya cepatnya infomasi mengenai seksualitas beredar. Bukan hanya itu, internet juga banyak menyediakan video-video yang dapat memicu syaraf seseorang dalam seksual dan ingin melakukannya dengan pasangannya. Siagian (2019) dengan beredarnya VCD dan majalah-majalah porno yang diperdagangkan begitu bebas disembarangan tempat, dapat membuat anak memperoleh sesuatu pengetahuan yang tidak benar dan ironisnya mereka akan cenderung mempraktekkan apa yang mereka baca dan tonton. Hal ini yang terjadi pada ARS (2017). Selain itu, teknologi juga dapat membuat seseorang yang tidak dikenal menjadi dikenal bahkan berlangsung pada hubungan pacaran yang sebenarnya si perempuan belum mengenal secara dalam dari karakter si laki-laki. Hal ini terjadi pada kasus ES (2019).

\section{Implikasi Bagi Pembinaan Pemuda Gereja}

Mencermati faktor-faktor penyebab terjadinya hamil di luar nikah pada pemuda gereja maka perlu pembinaan yang holistik, implikasinya bagi pembinaan pemuda gereja adalah:

\section{Komunitas Tumbuh Bersama}

Komunitas Tumbuh Bersama (KTB) merupakan sekelompok orang yang menyadari akan kasih karunia Allah dalam hidup mereka. Komunitas ini 
kemudian bertemu untuk belajar firman Tuhan, berbagi pengalaman, saling mendukung dan mendoakan dalam pemulihan karakter yang lebih baik dan bertumbuh sesuai dengan nilai-nilai Kekristenan. Komunitas Tumbuh Bersama ini dibuat oleh gereja atas hasil musyawarah antara pendeta dan majelis gereja untuk para pemuda gereja. Komunitas ini ada dengan tujuan menambah kegiatan-kegiatan yang positif bagi pemuda gereja di luar lingkungan keluarga dan sekolah daripada menghabiskan waktu berdua bersama pacar. Selain itu, KTB ini juga dapat menjadi sarana/tempat bagi pemuda dalam mengaktualisasikan bakat dan potensi, serta dapat memperkuat rasa persaudaraan antar sesama pemuda yang ada di gereja tersebut. Kegiatan-kegiatan positif dalam KTB ini dapat berupa diskusi, sharing, games, dan retreat rohani dengan mengkhususkan topik bagaimana pemuda harus bersikap bijak dalam mengendalikan pikiran dan emosi terhadap orang tuanya, terhadap pergaulannya, terhadap spiritualitasnya, dan juga bersikap bijak dan kreatif dalam memanfaatkan teknologi-teknologi yang ada.

Secara teoritis, KTB dapat berfungsi sebagai wadah pemuridan yang bertujuan agar anggota kelompok dapat menyadari karunia Allah melalui pendalaman Alkitab, kemudian berbagi pengalaman, memberikan dukungan dan doa sehingga akhirnya menjadi serupa dengan Kristus (Panuntun \& Paramita, 2019). Melalui KTB, pemuda Kristen juga dapat diarahkan untuk terus bertumbuh secara karakter yang mengarah pada Kristus sehingga dapat meminimalkan permasalahan pacaran yang tidak sehat dan hamil di luar nikah. Harmadi dan Diana (2020) melihat bahwa masalah perilaku seksual pada pemuda perlu ditangani dengan memberikan pembinaan iman Kristen sehingga mereka dapat bertumbuh secara rohani. Jika demikian maka KTB dapat dipilih sebagai cara pembinaan pemuda untuk menangani permasalahan pacaran yang berpotensi mengarah pada terjadinya masalah hamil di luar nikah.

Pembinaan melalui KTB dapat dikategorikan sebagai bagian dari pembinaan warga jemaat yang holistik. Nugroho (2017) berpendapat bahwa berbagai permasalahan yang terjadi di dalam gereja perlu ditangani melalui pembinaan yang holistik. Menurut Nugroho, gereja perlu mulai melibatkan kaum awam dalam pembinaan melalui kelompokkelompok kecil. Tentunya harus dilakukan dengan memperlengkapi mereka terlebih dahulu. Pola ini sejalan dengan penjelasan Darmawan $(2017,2019)$ tentang konsep pemuridan yang tergambar dalam Matius 28:19-20 dan mengarah pada terjadinya pertumbuhan rohani jemaat. Dengan diskusi dan pendalaman nilai-nilai Kristen sebgaimana ditekankan dalam Alkitab, maka pemuda Kristen dapat diarahkan mengalami perubahan pola pikir dan pertumbuhan rohani. Katarina dan Darmawan (2019) menjelaskan bahwa pemahaman Alkitab yang mendalam dapat mengarahkan pada terjadinya pembentukan karakter dan rohani yang dewasa. Dengan demikian, pemuda dapat menjadi lebih siap menghadapi tantangan masa muda mereka.

\section{Seminar Iman Kristen}

Seminar iman Kristen adalah sebuah bentuk pengajaran yang berdasarkan nilai-nilai Kekristenan. Tujuan seminar ini adalah untuk menambah wawasan dan pengetahuan. Seminar iman Kristen ini dibuat oleh gereja dan ditujukan kepada dua kategorial, yakni pemuda dan orangtua. Pertama, seminar iman Kristen kepada pemuda. Tema-tema yang diseminarkan adalah yang berkaitan dengan kehidupan pemuda seperti dampak dari pergaulan bebas, bijak dan kreatif dalam berteknologi, masalah narkoba, dan pacaran menurut nilai-nilai Kekristenan. Seminar tentang citra diri juga perlu dilakukan, sebab menurut penelitian Sitanggang dan Juantini (2019), masalah di lingkungan pemuda dapat disebabkan karena adanya citra diri yang buruk. Tafonao (2018) menekankan bahwa ada peran penting gembala untuk membantu pemuda mengalami pertumbuhan rohani. Dalam hal ini gembala dapat membantu menjawab kebutuhan rohani pemuda melalui penyelenggaraan seminar iman Kristen.

Kedua, seminar iman Kristen kepada orang tua. Seminar kepada orangtua mengundang para 
orang tua pemuda gereja dengan beberapa topik seperti pemuda dan lingkungan, pentingnya pendidikan seks, dan peranan dan tanggungjawab orangtua kepada anak. Diana (2019) menjelaskan bahwa ada singifikansi tanggung jawab orang tua dalam mendidik anak menghadapi berbagai perkembangan teknologi yang menyediakan berbagai kemudahan. Itu sebabnya orang tua perlu dipersiapkan menghadapi perkembangan dalam kaitannya dengan pendidikan anak mereka.

Walean (2018) menjelaskan bahwa dalam pembinaan di gereja, pengajaran iman Kristen umumnya dilaksanakan melalui katekisasi. Tetapi jika mencermati penjelasan Nugroho (2017) bahwa pembinaan warga gereja harus dilakukan secara holistik maka seminar iman Kristen dapat dipilih sebagai bentuk pembinaan pemuda.

\section{Personal Care}

Personal care dalam hal ini lebih mengarah kepada konseling dan pelayanan pastoral yang dilakukan pendeta dan majelis gereja yang sebelumnya sudah dibekali tentang strategi dalam konseling. Personal care ini lebih ditujukan kepada orang tua dengan fokus bagaimana seharusnya orang tua bersikap dan mendidik anaknya.

Dalam beberapa kasus, permasalahan moral umumnya mengarah pada terjadinya tindakan diskriminasi pada orang yang bermasalah. Padahal dalam masalah seperti ini orang yang bermasalah membutuhkan dukungan orang lain sehingga dapat menjadi sadar dan kembali bertumbuh dalam pengenalan akan Allah. Itu sebabnya dalam pembinaan terhadap pemuda yang bermasalah dalam kasus hamil di luar nikah, perlu tindakan kepedulian dari gereja agar mereka dapat terus bertumbuh. Dalam hal ini tentunya tidak mengabaikan sanksi disiplin gereja.

Tindakan personal care dapat dilakukan dengan mengadakan perkunjungan pastoral. Penelitian Widiyanto dan Susanto (2020) menunjukkan bahwa perkunjungan pastoral dapat membantu jemaat mengalami pertumbuhan rohani. Jika demikian, pembinaan melalui perkunjungan dapat diarahkan untuk membantu orang tua menjalankan perannya sebagai ayah/ibu yang dapat menjadi sahabat bagi diri anak-anak mereka.Selain itu, tindakan pastoral juga dapat menjadi kesempatan untuk membantu menjembatani masalah komunikasi antara anak dan orang tua. Dengan demikian dapat diminimalkan permasalah pacaran yang tidak baik dan yang mengarah para perilaku seks di luar nikah.

\section{Silabus Khusus Tentang Seksualitas}

Mencermati masalah yang terjadi sebagaimana digambarkan di atas maka dapat dibuat silabus katekisasi khusus tentang seksualitas menurut iman Kristen dalam katekisasi sidi. Setiap anggota gereja HKBP akan menjalani masa katekisasi sebelum di sidi. Masa ini dapat menjadi masa pembinaan pemuda sehingga dapat memperlengkapi pemuda HKBP menjadi pemuda Kristen yang dewasa secara rohani. Leuwol (2018, p. 32) mengungkapkan bahwa katekisasi perlu dilakukan bagi pemuda yang akan menjalani sidi agar dapat membantu pemuda memahami iman Kristen yang kemudian ditunjukkan dalam kehidupan sehari-hari. Menurut Leuwol dengan katekisasi yang baik, pemuda Kristen dapat dipersiapkan menjadi lebih dewasa secara rohani dan akhirnya merealisasikan imannya dalam kehidupan sehari-hari. Dalam mencermati masalah yang digambarkan di atas, maka menurut penulis perlu sebuah katekisasi yang khusus membahas tentang seksualitas sehingga iman Kristen direalisasikan dalam kehidupan pergaulan pemuda.

Picanussa (2019, p. 12) mengungkapkan bahwa pendidikan dalam gereja berfungsi untuk membina warga gereja bertumbuh secara iman dan kehidupan kristiani. Oleh sebab itu, Picanussa mengungkapkan bahwa perlu sebuah kurikulum yang dapat menjadi acuan agar proses pembinaan dapat dijalankan dengan terarah dan sesuai tujuan pendidikan dalam gereja. Secara umum, silabus merupakan rencana pembelajaran pada suatu kelompok yang mencakup standar kompotensi, kompotensi dasar, materi pokok/pembelajaran, dan metode pembelajaran. Untuk silabus dalam katekisasi sidi di gereja biasanya 
membicarakan materi tentang isi Alkitab, dogma gereja, sejarah gereja, dan peribadahan. Silabus dalam katekisasi sidi dibuat oleh katekumen (pengajar)/majelis gereja. Tetapi dalam tulisan ini penulis menawarkan adanya silabus khusus yang berisikan materi seksualitas menurut iman Kristen. Tujuan dari materi ini agar pemuda dapat mengetahui bentuk seksualitas yang wajar dilakukan sebagai pemuda Kristen dan agar pemuda dapat menjaga sikap dalam berpacaran. Berikut penulis menyertakan contoh topik-topik dari materi seksualitas menurut iman Kristen yang dapat dibuat di katekisasi sidi gereja: 1) Pengertian seks dan seksualitas, 2) Faktor-faktor yang mempengaruhi seksualitas, 3) Seksualitas bagi pemuda, 4) Seks dalam pola ciptaan Allah, 5) Seks dalam pernikahan, 6) Seks di luar pernikahan, 7) Hubungan antara kasih dan seks, 8) Kesucian dan kesopanan menurut Alkitab.

\section{KESIMPULAN}

Pacaran yang ditinjau dari segi iman Kristen adalah sebuah relasi yang lebih dari sekedar teman untuk dapat saling mengenal sebelum masuk kepada tahap pernikahan. Tujuan utama dari pacaran itu adalah untuk mengenal lebih dalam bagaimana pola pikir dan karakter dari pasangan. Dalam proses pacaran itu juga akan terlihat bagaimana kesungguhan seorang laki-laki menyayangi seorang perempuan dan bagaiman tanggung jawab dari seorang laki-laki kepada seorang perempuan sebelum menjadikannya seorang istri. Pacaran yang ditinjau dari segi iman Kristen juga adalah hubungan yang dilakukan oleh laki-laki dan perempuan dalam kerangka kasih Allah itu sendiri. Oleh karena itu, apapun alasannya, di

\section{DAFTAR PUSTAKA}

Andriani, H. (2014). Pergaulan Bebas di Kalangan Remaja yang Mengkhawatirkan [KOMPASIANA]. Retrieved 3 March 2020, from Edukasi website: https://www.kompasiana. com/harniandriani/54f93d6aa3331112678b4 c33/pergaulan-bebas-di-kalangan-remajayang-mengkhawatirkan luar kerangka rumah tangga antara suami dan istri, hubungan seks tidak boleh dilakukan. Hubungan seks hanya boleh dilakukan ketika sudah memasuki tahap pernikahan dan fungsi utamanya adalah menghasilkan keturunan (Kej. 1:28). Tujuan pacaran yang ditinjau dari segi iman Kristen, adalah pacaran bukanlah sarana pemuasan nafsu, pacaran bukan sekedar pemberi motivasi belajar atau bekerja, pacaran bukan untuk mengisi kesepian, dan pacaran bukan sekedar free-life tanpa arah yang jelas.

Dari faktor masalah yang ditemukan, maka implikasi yang penulis kemukakan bagi pembinaan pemuda gereja adalah 1) Perlu dilaksanakan KTB sebagai upayan pembinaan pendalaman Alkitab dan rohani; 2) Perlu penyelenggaraan seminar iman Kristen yang menjawab kebutuhan rohani pemuda gereja. Seminar ini juga perlu melibatkan orang tua agar dapat membangun pengertian bersama; 3) Perlu personal care melalui konseling dan pelayanan pastoral yang dilakukan pendeta dan majelis gereja yang sebelumnya sudah dibekali tentang strategi dalam konseling. Personal care ini lebih ditujukan kepada orang tua dengan fokus bagaimana seharusnya orang tua bersikap dan mendidik anaknya. Melalui pola ini diharapkan ada mediator yang menjembatani persoalan komunikasi antara pemuda dengan orang tua; 4) Perlu pembuatan silabus katekisasi khusus tentang seksualitas. Setiap anggota HKBP akan menjalani katekisasi sebelum sidi. Proses ini dapat menjadi bagian dalam pembinaan pemuda sehingga dapat membangun kesadaran hidup kudus dan perilaku seks yang Alkitabiah.

Anggito, A., \& Setiawan, J. (2018). Metodologi penelitian kualitatif. Sukabumi: CV Jejak (Jejak Publisher).

Anwar, H. K., Martunis, M., \& Fajriani, F. (2019). Analisis Faktor-Faktor Penyebab Terjadinya Pergaulan Bebas Pada Remaja Di Kota Banda Aceh. JIMBK: Jurnal Ilmiah Maha- 
siswa Bimbingan \& Konseling, 4(2). Retrieved from http://jim.unsyiah.ac.id/pbk/article/ view/10065

ARS. (2017, February 15). Apa Faktor Penyebab Seks Di Luar Nikah?

Chalke, S. (2007). Orang tua, Anak dan Seks. Yogyakarta: Andi Offset.

Darmawan, I. P. A. (2017). Murid yang Memuridkan. In Melaksanakan Amanat Agung Di Abad 21. Ungaran: Sekolah Tinggi Teologi Simpson.

Darmawan, I. P. A. (2019). Jadikanlah Murid: Tugas Pemuridan Gereja Menurut Matius 28:1820. Evangelikal: Jurnal Teologi Injili dan Pembinaan Warga Jemaat, 3(2), 144-153.

DeGenova, M. K., Rice, F. P., Stinnett, N., \& Stinnett, N. (2010). Intimate Relationships, Marriages, and Families (8 edition). New York, NY: McGraw-Hill Education.

Diana, R. (2019). Prinsip Teologi Kristen Pendidikan Orang tua terhadap Anak di Era Revolusi Industri 4.0. BIA': Jurnal Teologi Dan Pendidikan Kristen Kontekstual, 2(1), 27-39. https://doi.org/10.34307/b.v2i1.79

ES. (2019, February 18). Faktor Penyebab Mengapa Sampai Terjadi Hamil di Luar Nikah.

Gaol, S. M. M. L., \& Stevanus, K. (2019). Pendidikan Seks Pada Remaja. FIDEI: Jurnal Teologi Sistematika dan Praktika, 2(2), 325-343.

https://doi.org/10.34081/fidei.v2i2.76

Gunarsa, Ny. Y. S. D., \& Gunarsa, S. D. (1987). Psikologi untuk muda mudi (Vol. 1987). Jakarta: BPK Gunung Mulia.

Harmadi, M., \& Diana, R. (2020). Tinjauan PsikoTeologi Terhadap Fenomena Kekerasan Dalam Pacaran Pada Remaja. Evangelikal: Jurnal Teologi Injili dan Pembinaan Warga Jemaat, 4(1), 92-102.

Illu, W., \& Masihoru, O. (2020). Upaya Gereja Dalam Pembinaan Usia Remaja Yang Melakukan Hubungan "Free Seks". Missio Ecclesiae, 9(1), 1-19.
Katarina, K., \& Darmawan, I. P. A. (2019). Implikasi Alkitab dalam Formasi Rohani pada Era Reformasi Gereja. EPIGRAPHE: Jurnal Teologi Dan Pelayanan Kristiani, 3(2), 81-93. https://doi.org/10.33991/ epigraphe.v3i2.85

Leuwol, N. V. (2018). Pendidikan Katekisasi Kepada Remaja Di Jemaat GKI Kasih Perumnas Sorong. J-DEPACE (Journal of Dedication to Papua Community), 1(1), 32 41. https://doi.org/10.34124/269162

Magdalena, M. (2010). Melindungi anak dari seks bebas. Jakarta: Gramedia Widiasarana Indonesia.

Mathews, K. (2005). Genesis 11:27-50:26: An Exegetical and Theological Exposition of Holy Scripture. Nashville, Tenn.: Holman Reference.

Miles, H. J. (2000). Sexual Understanding Before Marriage. Michigan: Zondervan Publishing Company.

MS. (2019, February 14). Faktor Penyebab Menyetujui Berhubungan Seks.

Nadesul, H. (2009). Kiat Sehat Pranikah. Jakarta: Penerbit Buku Kompas.

Nugroho, F. J. (2017). Pendampingan Pastoral Holistik: Sebuah Usulan Konseptual Pembinaan Warga Gereja. Evangelikal: Jurnal Teologi Injili dan Pembinaan Warga Jemaat, 1(2), 139-154.

Oden, T. C. (Ed.). (2006). Ancient Christian Commentary on Scripture CD-ROM, Volume 1. Altamonte Springs, Fla: IVP Academic.

Pangaribuan, A. Ch. V. (2015). Konseling Pastoral untuk Pranikah dan Keluarga. Pematangsiantar: L-SAPA.

Panuntun, D. F., \& Paramita, E. (2019). Hubungan Pembelajaran Alkitab Terhadap Nilai-Nilai Hidup Berbangsa Dalam Pemuridan Kontekstual (Kelompok Tumbuh Bersama Kontekstual). Jurnal Gamaliel: Teologi Praktika, 1(2), 104-115. 
Picanussa, B. E. (2019). Pengembangan Kurikulum Pendidikan Kristiani. Voice of Wesley: Jurnal Ilmiah Musik dan Agama, 3(1), 1-15. https://doi.org/10.36972/jvow.v3i1.30

Purwanto, H. (2016). Manfaat Penelitian Untuk Perkembangan Gereja. Prosiding Seminar Nasional Pendidikan Agama Kristen STT Simpson Tahun 2016 Tema: Strategi Pembinaan Jemaat Untuk Meningkatkan Kehidupan Jemaat. Presented at the Seminar Nasional Pendidikan Agama Kristen \& call for papers, Ungaran.

SELS. (2019, February 21). Faktor Penyebab Seks di Luar Nikah hingga Hamil.

Siagian, F. (2019). Penyalahgunaan Seks Dikalangan Pemuda Dalam Perspektif Al Kitab Menurut I Korintus 6:12-20. Syntax Literate; Jurnal Ilmiah Indonesia, 4(5), 4463.

Sitanggang, M. H., \& Juantini, J. (2019). Citra Diri Menurut Kejadian 1:26-27, Dan Aplikasinya Bagi Pengurus Pemuda Remaja GPDI Hebron-Malang. Evangelikal: Jurnal Teologi Injili Dan Pembinaan Warga Jemaat, 3(1), 49-61.

Sujarwati, S., Yugistyowati, A., \& Haryani, K. (2014). Peran Orang Tua dan Sumber Informasi dalam Pendidikan Seks dengan Perilaku Seksual Remaja pada Masa Pubertas di SMAN 1 Turi. Jurnal Ners Dan Kebidanan Indonesia, 2(3), 112-116. https://doi.org/10.21927/jnki.2014.2(3).112116

Tafonao, T. (2018). Peran Gembala Sidang Dalam Mengajar Dan Memotivasi Untuk Melayani Terhadap Pertumbuhan Rohani Pemuda. Evangelikal: Jurnal Teologi Injili dan Pembinaan Warga Jemaat, 2(1), 36-49.

Towsend, J., \& Cloud, H. (2008). Intimacy, Sex, and God. Yogyakarta: Gloria Graffa.

Tu'u, T. (2000). Etika dan Pendidikan Seksual. Bandung: Yayasan Kalam Hidup.

Viviano, P. A. (2002). Kejadian 29:15-30. In Tafsir Alkitab Perjanjian Lama. Yogyakarta: Kanisius.

Walean, J. (2018). Kateketika Dalam Sejarah Pemikiran Pedagosis Kristen. Evangelikal: Jurnal Teologi Injili dan Pembinaan Warga Jemaat, 2(2), 105-114.

Widiyanto, M. A., \& Susanto, S. (2020). Pengaruh Pelayanan Kunjungan Pastoral Terhadap Pertumbuhan Rohani Jemaat. Evangelikal: Jurnal Teologi Injili Dan Pembinaan Warga Jemaat, 4(1), 39-46.

Zaluchu, S. E. (2020). Strategi Penelitian Kualitatif dan Kuantitatif Di Dalam Penelitian Agama. Evangelikal: Jurnal Teologi Injili dan Pembinaan Warga Jemaat, 4(1), 28-38.

Zohar, D., \& Marshal, I. (2001). SQ;Memanfaatkan Kecerdasan Spiritual dan Berfikir Integralistik dan Holistik Untuk Memaknai Kehidupan (III; R. Astuti, Trans.). Bandung: Mizan. 